\title{
Allogeneic BK Virus-Specific T-Cell Treatment in 2 Patients With Progressive Multifocal Leukoencephalopathy
}

Franziska Hopfner, MD, Nora Möhn, MD, Britta Eiz-Vesper, PhD, Britta Maecker-Kolhoff, MD, Jens Gottlieb, MD, Rainer Blasczyk, MD, Nima Mahmoudi, MD, Kaweh Pars, MD, Ortwin Adams, MD, PhD, Martin Stangel, MD, Mike P. Wattjes, MD, Günter Höglinger, MD, and Thomas Skripuletz, MD

Neurol Neuroimmunol Neuroinflamm 2021;8:e1020. doi:10.1212/NXI.0000000000001020

\section{Abstract}

\section{Objective}

Progressive multifocal leukoencephalopathy (PML) is a devastating demyelinating opportunistic infection of the brain caused by the ubiquitously distributed JC polyomavirus. There are no established treatment options to stop or slow down disease progression. In 2018, a case series of 3 patients suggested the efficacy of allogeneic BK virus-specific T-cell (BKV-CTL) transplantation.

\section{Methods}

Two patients, a bilaterally lung transplanted patient on continuous immunosuppressive medication since 17 years and a patient with dermatomyositis treated with glucocorticosteroids, developed definite PML according to AAN diagnostic criteria. We transplanted both patients with allogeneic BKV-CTL from partially human leukocyte antigen (HLA) compatible donors. Donor $\mathrm{T}$ cells had directly been produced from leukapheresis by the CliniMACS IFN- $\gamma$ cytokine capture system. In contrast to the previous series, we identified suitable donors by HLA typing in a preexamined registry and administered 1 log level less cells.

\section{Results}

Both patients' symptoms improved significantly within weeks. During the follow-up, a decrease in viral load in the CSF and a regression of the brain MRI changes occurred. The transfer seemed to induce endogenous BK and JC virus-specific $\mathrm{T}$ cells in the host.

\section{Conclusions}

We demonstrate that this optimized allogeneic BKV-CTL treatment paradigm represents a promising, innovative therapeutic option for PML and should be investigated in larger, controlled clinical trials.

\section{Classification of Evidence}

This study provides Class IV evidence that for patients with PML, allogeneic transplant of BKVCTL improved symptoms, reduced MRI changes, and decreased viral load.

\author{
Correspondence \\ Dr. Hopfner \\ Hopfner.Franziska@ \\ mh-hannover.de
}

\section{MORE ONLINE}

\section{Class of Evidence}

Criteria for rating therapeutic and diagnostic studies

NPub.org/coe

\footnotetext{
From the Department of Neurology (F.H., N. Möhn, M.S., G.H., T.S.), Hannover Medical School; Institute of Transfusion Medicine and Transplant Engineering (B.E.-V., R.B.), Hannover Medical School; Department of Pediatric Hematology and Oncology (B.M.-K.), Hannover Medical School; Hannover Medical School (B.M.-K.), Institute for Transfusion Medicine; Department of Respiratory Medicine (J.G.), Hannover Medical School; Department of Diagnostic and Interventional Neuroradiology (N. Mahmoudi, M.P.W.), Hannover Medical School, Hannover; Department of Neurology (N. Mahmoudi, K.P., M.P.W.), Carl Von Ossietzky University, Oldenburg; and Institute of Virology (O.A.), Medical Faculty, Heinrich-Heine University Düsseldorf, Germany.

Go to Neurology.org/NN for full disclosures. Funding information is provided the end of the article.

F. Hopfner, N. Möhn, and B. Eiz-Vesper are first authors and contributed equally to this work.
}

M.P. Wattjes, G.U. Höglinger, and T. Skripuletz are senior authors and contributed equally to this work.

The Article Processing Charge was funded by the authors.

This is an open access article distributed under the terms of the Creative Commons Attribution-NonCommercial-NoDerivatives License 4.0 (CC BY-NC-ND), which permits downloading and sharing the work provided it is properly cited. The work cannot be changed in any way or used commercially without permission from the journal. 


\section{Glossary}

BKV-CTL = BK virus-specific T-cell; HLA = human leukocyte antigen; PML = progressive multifocal leukoencephalopathy; $\mathrm{JCPyV}=\mathrm{JC}$ polyomavirus; JCVAI = anti-JC virus antibody index.

Progressive multifocal leukoencephalopathy (PML) is an opportunistic infection of the brain caused by reactivation of JC polyomavirus (JCPyV), for which about $50 \%$ of the adult general population is seropositive. ${ }^{1}$ The spectrum of underlying immunosuppressive conditions, mainly affecting cellmediated immunity, is broad including lymphoproliferative diseases, immunosuppressive and immunomodulatory therapies, and solid organ malignancies. Morbidity and mortality are relatively high, depending on the underlying immunosuppressive condition, particularly because of a lack of targeted therapies. ${ }^{2}$ Rapid reconstitution of T-cell-mediated immunity in immunocompromised patients is the most promising strategy to treat reactivation of latent viral diseases. Virus-specific T-cell treatment is nowadays established to treat BK virus infection after stem-cell transplantation. BK virus (B.K. as the initials of a renal transplant patient) and JCPyV belong to the Polyomaviridae family and share immunogenic epitopes that can be targeted by the immune system. Because of these similarities, $T$ cells developed against $\mathrm{BK}$ virus are strongly effective against $\mathrm{JCPyV}$ infection, as previously shown. A few case series of patients with PML transplanted with allogeneic BK virus-specific $\mathrm{T}$ cells $(\mathrm{BKV}$ CTL) demonstrated alleviation of symptoms, demyelinating lesions, and JC virus load. ${ }^{3-5}$ In this study, we treated 2 patients with PML successfully with allogeneic BKV-CTL using different protocols for the donor cell preparation and different T-cell monitoring approaches.

\section{Methods}

Detailed information on JCPyV PCR, anti-JC virus antibody index $\left(\mathrm{JCV}_{\mathrm{AI}}\right)$, standardized multisequence MRI protocol, preparation of donor $\mathrm{T}$ cells for adoptive transfer, and detection of BKV-CTLs in patients' blood is presented in the supplemental online material (links.lww.com/NXI/A494).

\section{Criteria for Rating Therapeutic Studies}

The criteria for rating therapeutic studies based on the AAN Guidelines Committee classified the level of evidence in this study examining allogeneic BKV-CTL treatment as a Class IV evidence.

\section{Case Description and Disease Course}

Both participants had given written informed consent. Approval from the corresponding ethics committee has been provided.

\section{Case 1}

A 55-year-old woman was diagnosed with definite PML based on the clinical-neurologic presentation, multifocal lesions on brain MRI suggestive of PML, and detection of JCPyV DNA in
CSF (figure). ${ }^{6}$ Twenty-four years before the manifestation of PML, she had been diagnosed with Hodgkin lymphoma. Seven years later, she had been transplanted with autologous hematopoietic stem cells. Radiation and chemotherapy (dexamethasone + cytarabine + cisplatin, high-dose cyclophosphamide, methotrexate, etoposide, and vincristine) led to pulmonary graft vs host disease, resulting in bilateral lung transplantation and consecutive immunosuppressive treatment. At the time of PML diagnosis, she was treated with mycophenolate mofetil (2 $\mathrm{g} / \mathrm{d})$, tacrolimus $(3 \mathrm{mg} / \mathrm{d})$, and methylprednisolone $(7.5 \mathrm{mg} /$ d). Regarding immune status, the patient was regularly examined. The absolute lymphocyte counts proved to be consistent within the reference range. The patient presented with reduced mental status affecting alertness, attention, and orientation. The speech was slow and dysarthric. Ocular pursuit movements were saccadic. She presented general weakness in both arms and legs. She was bedridden because of ataxia in all limbs, with unsteady stance and walk. The patient's MRI showed multifocal bilateral confluent white matter lesions without contrast enhancement, suggestive of blood-brain barrier dysfunction. The brain lesions progressively increased. Two and a half months after first clinical symptoms, a diagnosis of PML was established, immunosuppressive therapy was switched to a calcineurin inhibitor-free protocol comprising mycophenolate mofetil $(1 \mathrm{~g} / \mathrm{d})$, everolimus $(3 \mathrm{mg} / \mathrm{d})$, and prednisolone $(7.5$ $\mathrm{mg} / \mathrm{d}$ ), and allogeneic BKV-CTLs were transplanted. In total, she received 4 infusions of BKV-CTLs (each: $2.5 \times 10 \mathrm{e} 4 \mathrm{CD}^{+}$ $\mathrm{T}$ cells per $\mathrm{kg}$ body weight, 1 fresh and 3 cryopreserved products) within 5 months. An initial strong increase in CSF viral load before BKV-CTL administration (9.840-19.000 copies $/ \mathrm{mL}$ ) was followed by a significant decrease in viral load to 500 copies $/ \mathrm{mL}$ after BKV-CTL administration. Furthermore, we detected a antibody reaction in CSF after BKV-CTL administration during the treatment period, as shown by an elevated $\mathrm{JCV}_{\mathrm{AI}} 2.4$ (figure ). Fourteen days after first BKV-CTL administration, patient's symptoms started to improve. Three months after initiation, cerebral MRI demonstrated no new lesions (no increased signal intensity in the diffusion-weighted imaging sequence and no lesioned areas with decreased apparent diffusion coefficient), indicating stabilization of disease progression (figure). The frontal lobar lesions even had regressed in size. Ten weeks after initiation, she was able to stand and walk unaided. In the further course, comprehensibility of her speech significantly improved. Lung tissue biopsies excluded acute cellular rejection during the follow-up.

\section{Case 2}

A 71-year-old woman presented with a progressive cerebellar syndrome. A diagnosis of definite PML was reached by the detection of JCPyV DNA in CSF (figure). ${ }^{6}$ Sixteen years 
Figure MRI and CSF Measured JC Virus Load Before During and After BK Virus-Specific T-Cell Therapy in Patient 1 (A and B) and Patient 2 (C and D)

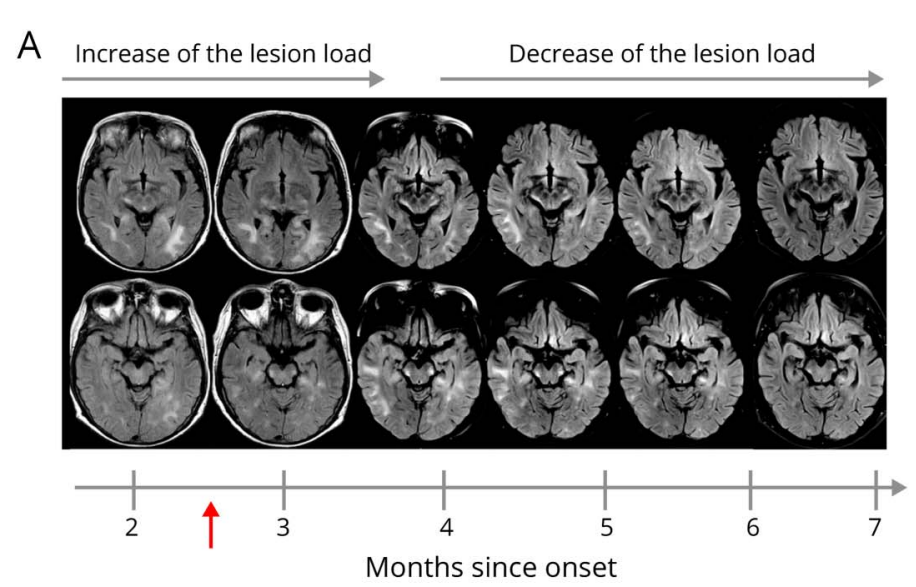

C

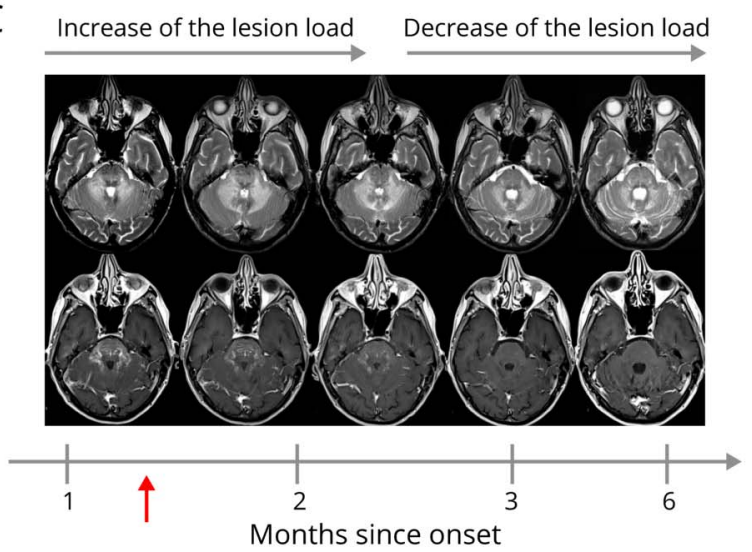

B

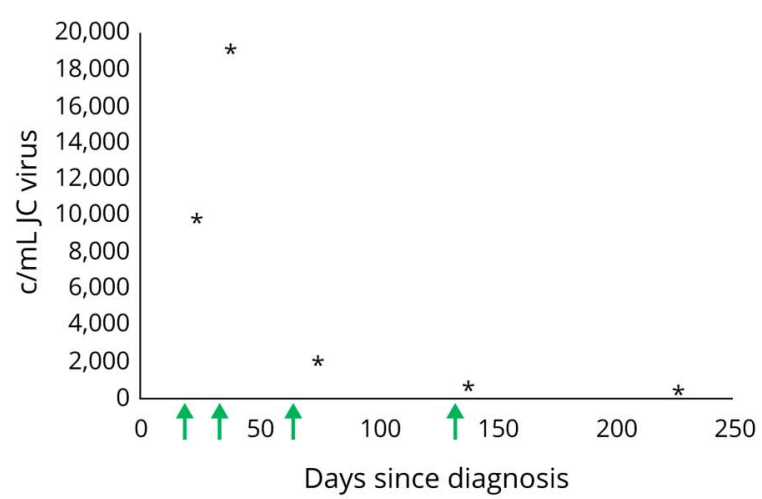

D

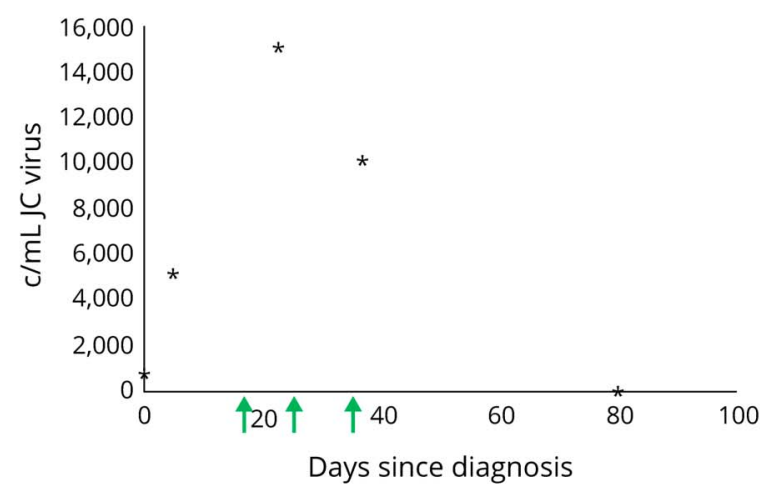

(A) Axial FLAIR sections on multiple time points before and during BKV-CTL therapy. Increasing PML lesions in the first 3 months. Stagnation/slight regression of lesions from the fourth month on. BKV-CTL therapy had been implemented at third month. Red arrow: month of PML diagnosis since symptom onset by the detection of JCPyV DNA in CSF. (B) JC virus load (c/mL) before, during, and after BKV-CTL therapy measured in patient's CSF. X-axis: days since diagnosis; $y$-axis: $\mathrm{c} / \mathrm{mL}$ JC virus; and green arrows: infusions of BKV-CTL. (C) Axial T2-weighted (top row) and contrast-enhanced T1-weighted (bottom row) sections on multiple time points before and during BKV-CTL therapy. Increasing PML lesions in the first 2 months. Regression of lesions from the second month on. In addition, regression of the contrast enhancement could be observed. BKV-CTL therapy had been implemented at first month. Red arrow: month of PML diagnosis since symptom onset by the detection of JCPyV DNA in CSF. (D) JC virus load (c/mL) before, during, and after BKV-CTL therapy measured in patient's CSF. $x$-axis: days since diagnosis; $y$-axis c/mL JC virus; and green arrows: infusions of BKV-CTL. BKV-CTL = BK virus-specific T cell; JCPyV = JC polyomavirus; PML = progressive multifocal leukoencephalopathy.

before PML onset, the patient had been diagnosed with breast cancer and treated by resection, cisplatin-containing chemotherapy, and radiation. Coincidentally, she had been diagnosed with dermatomyositis and permanently treated with prednisolone $(2 \mathrm{mg} / \mathrm{d})$. Lymphocyte counts were within the reference range despite treatment. On PML diagnosis, she presented cachexia, severe dysarthria, dysphagia, saccadic eye movements, a severe cerebellar syndrome with pronounced ataxia of the upper and lower limbs, and pronounced tremor of trunk and head. She was bedridden because of severely impaired stance and gait. Alertness and higher cognitive functions were preserved. Allogeneic BKV-CTL therapy was initiated 1 month after the diagnosis of PML and 3 months after initial clinical symptoms. In total, the patient received 3 infusions of BKV-CTLs (each: $2.5 \times 10 \mathrm{e} 4 \mathrm{CD}^{+}{ }^{+} \mathrm{T}$ cells per $\mathrm{kg}$ body weight, 1 fresh and 2 cryopreserved products) within 3 months. Four weeks after the initiation of therapy, her symptoms started to improve. After 4 months, most disabilities including dysarthria, dysphagia, tremor, and ataxia had markedly improved. At the time of PML diagnosis, MRI demonstrated pronounced bilateral T2-hyperintense lesions of the cerebellar dentate nuclei, upper and middle cerebellar peduncles, and the pons and widespread contrast enhancement of the brain parenchyma with leptomeningeal spread without clinical evidence of immune reconstitution (figure). Two months after the initiation of BKV-CTL therapy, the lesions were stable or slightly regressive. In this patient, the CSF virus load increased after the first infusion of BKV-CTLs (1.000-15.000 copies/mL) and decreased to values below the detection limit during the treatment period (figure ).

\section{Discussion}

Here, we demonstrate the safety and efficacy of allogeneic BKV-CTLs in 2 patients severely affected by PML. Both 
patients improved clinically and radiologically and generated a specific immune response against both $\mathrm{BK}$ virus and JCPyV. An increase in the JCPyV antibody specificity index was detectable. Human leukocyte antigen (HLA) phenotyping of BKV-CTLs after therapy showed that the patients themselves produced endogenous BK and JC virus-specific $\mathrm{T}$ cells after transfer.

The attribution on the therapeutic response to the cell therapy must be interpreted with due care. In the first patient, the immunosuppressive therapeutic regimen was changed from tacrolimus to everolimus before BKV-CTL therapy without a negative effect of continued mandatory immunosuppressive medication on the T-cell treatment. Because everolimus has previously been reported to exhibit an antiviral effect and to increase mTOR activity in PML, this might have influenced the course. ${ }^{7}$ However, in our second patient only, the effects of BKV-CTLs were observed because the drug regimen remained unchanged.

Our observations support the conclusions drawn from a previous series of patients treated with allogeneic BKV-CTLs. ${ }^{3-5}$ Although the therapeutic responses in these studies are consistent, there were major differences in the protocols to prepare the donor cells. The preceding case series applied preproduced frozen cell lines from autologous or allogeneic peripheral blood mononuclear cells by stimulation with JCPyV antigen-derived peptides. ${ }^{3-5}$ By contrast, we have accessed a preexamined registry of $>2,000$ potential donors and identified the most suitable donors based on HLA typing and T-cell frequencies. Direct isolation of antigen-specific $\mathrm{T}$ cells by stimulation with peptide pools followed by cytokine capture and magnetic isolation provides a rapid method to produce antiviral $\mathrm{T}$ cells under good manufacturing production guidelines within 16-24 hours. ${ }^{8,9}$ Furthermore, the previous case series administered 2 $\times 10 \mathrm{e} 5$ allogeneic BKV-CTLs (terminally differentiated cells) per kg body weight, whereas we followed the cell dose for HLA nonidentical stem-cell transplants and administered 10-times less $\mathrm{T}$ cells per $\mathrm{kg}$ body weight $(2.5 \times 10 \mathrm{e} 4)$.

To date, a variety of treatment strategies have failed to provide a conclusive positive effect on the outcome of patients with PML. ${ }^{10}$ Immune checkpoint inhibitor therapy with the anti-PD1antibodies pembrolizumab and nivolumab has been suggested to show beneficial effects in single PML patients by increasing $\mathrm{CD}^{+}$and $\mathrm{CD}^{+}{ }^{+}$T-cell activity against the JCPyV and consecutively reducing JCPyV viral load. ${ }^{11,12}$ However, in patients with preexisting autoimmune diseases or patients after solid organ transplantation, as in case 1, this therapy is not a suitable option because of possible autoimmune side effects and graft rejection. ${ }^{13}$

In conclusion, allogeneic BKV-CTL transplantation represents a promising therapeutic option for PML, requiring confirmation in controlled clinical trials.

\section{Acknowledgment}

The authors are grateful to the following colleagues for their help in patient care: Sandra Nay, Daria Tkachenko, Tilmann
Riesmeier, and Adrian Stender. The authors thank Sabine Tischer-Zimmermann and Agnes Bonifacius for help in T-cell donor selection, quality control, and monitoring of T-cell frequencies. This work was partially funded by the German Research Foundation.

\section{Study Funding}

The authors report no targeted funding.

\section{Disclosure}

F. Hopfner received grants from the German Research Council (DFG), the EASI-Genomics Consortium (Horizon 2020), and the Erwin-Röver-Foundation. N. Möhn received speaker honoraria from Merck Serono and Novartis. She was supported by Bristol-Myers Squibb ImmunonkologieStiftung (FA 19-010) and Claudia von Schilling Stiftung. B. Maecker-Kolhoff and B. Eiz-Vesper were funded by the German Research Foundation (DFG; SFB 900/B11 project ID 158989968). J. Gottlieb, N. Mahmoudi, K. Pars, and O. Adams reported no disclosures. R. Blasczyk received funding from the Federal Ministry of Health (BMG), the European Union (European Regional Development Fund, ERDF), the State Ministry of Science and Art of Lower Saxony (MWK NDS), and the Foundation of the Red Cross Blood Donation Service of Lower Saxony (DRK BSD NSTOB). K. Pars received grants from Carl Von Ossietzky University for research, honoria for courses and seminars, grants as a member of the Merck Neuroakademie, and received financial compensations as a speaker and consultant in advisory boards from Novartis, Biogen, Roche, and Sanofi-Aventis. M. Stangel received grants from the German Research Council (DFG, German Research Foundation) under Germany's Excellence Strategy - EXC 2155 - Projektnummer 390874280 and Niedersächsisches Ministerium für Wissenschaft und Kunst (MWK): REBIRTH - Forschungszentrum für translationale regenerative Medizin. His institution received research support from Sanofi-Aventis, Novartis, and Merck-Serono. M. Stangel has received honoraria for scientific lectures or consultancy from Alexion, Bayer Healthcare, Biogen, Celgene, CSL Behring, Grifols, Janssen, MedDay, Merck-Serono, Novartis, Roche, Sanofi-Aventis, Takeda, and Teva. M.P. Wattjes received speaker or consultancy honoraria from Bayer Healthcare, Biogen, Biologix, Celgene, Genilac, Imcyse, IXICO, Medison, Merck-Serono, Novartis, Roche, and Sanofi-Genzyme. G.U. Höglinger was supported by the German Federal Ministry of Education and Research (BMBF: 01KU1403A EpiPD), Deutsche Forschungsgemeinschaft (DFG, German Research Foundation) under Germany's Excellence Strategy within the framework of the Munich Cluster for Systems Neurology (EXC 2145 SyNergy - ID 390857198), DFG grants (HO2402/6-2, HO2402/18-1 MSAomics), the NOMIS foundation (FTLD project), and the EU/EFPIA/Innovative Medicines Initiative, Joint Undertaking (IMPRIND grant $\mathrm{n}^{\circ}$ 116060). T. Skripuletz reported grants from Bristol-Myers Squibb and Sanofi Aventis and personal fees from Alexion, Alnylam, Bayer Vital, Biogen, Celgene, CSL Behring, Euroimmun, Merck, Novartis, Roche, 
Sanofi Aventis, Siemens, and all outside the submitted work. All authors are government employees. K. Pars is employee of Evangelisches Krankenhaus Oldenburg and Carl Von Ossietzky University Oldenburg. Go to Neurology.org/NN for full disclosures.

\section{Publication History}

Received by Neurology: Neuroimmunology \& Neuroinflammation January 10, 2021. Accepted in final form March 29, 2021.

\section{References}

1. Brew BJ, Davies NW, Cinque P, Clifford DB, Nath A. Progressive multifocal leukoencephalopathy and other forms of JC virus disease. Nat Rev Neurol. 2010;6(12):667-679.

2. Cortese I, Reich DS, Nath A. Progressive multifocal leukoencephalopathy and the spectrum of JC virus-related disease. Nat Rev Neurol. 2020;17(1):37-21.

3. Muftuoglu M, Olson A, Marin D, et al. Allogeneic BK virus-specific $\mathrm{T}$ cells for progressive multifocal leukoencephalopathy. N Engl J Med. 2018;379(15):1443-1451.

4. Berzero G, Basso S, Stoppini L, et al. Adoptive transfer of JC virus-specific T lymphocytes for the treatment of progressive multifocal leukoencephalopathy. Ann Neurol. 2021;89(4):769-779.
5. Steinhardt MJ, Wiercinska E, Pham M, et al. Progressive multifocal leukoencephalopathy in a patient post allo-HCT successfully treated with JC virus specific donor lymphocytes. J Transl Med. 2020;18(1):177.

6. Berger JR, Aksamit AJ, Clifford DB, et al. PML diagnostic criteria: consensus statement from the AAN Neuroinfectious Disease Section. Neurology. 2013;80(15): 1430-1438.

7. Tan L, Sato N, Shiraki A, et al. Everolimus delayed and suppressed cytomegalovirus DNA synthesis, spread of the infection, and alleviated cytomegalovirus infection. Antivir Res. 2019;162:30-38.

8. Priesner C, Aleksandrova K, Esser R, et al. Automated enrichment, transduction, and expansion of clinical-scale CD62L(+) T cells for manufacturing of gene therapy medicinal products. Hum Gene Ther. 2016;27(10):860-869.

9. Priesner C, Esser R, Tischer S, et al. Comparative analysis of clinical-scale IFN gamma-Positive T-cell enrichment using partially and fully integrated platforms. Front Immunol. 2016;7:393.

10. Dunham SR, Schmidt R, Clifford DB. Treatment of progressive multifocal leukoencephalopathy using immune restoration. Neurotherapeutics. 2020;17(3):955-965.

11. Cortese I, Muranski P, Enose-Akahata Y, et al. Pembrolizumab treatment for progressive multifocal leukoencephalopathy. N Engl J Med. 2019;380(17):1597-1605.

12. Walter O, Treiner E, Bonneville F, et al. Treatment of progressive multifocal leukoencephalopathy with nivolumab. N Engl J Med. 2019;380(17):1674-1676.

13. Fisher J, Zeitouni N, Fan W, Samie FH. Immune checkpoint inhibitor therapy in solid organ transplant recipients: a patient-centered systematic review. J Am Acad Dermatol. 2020;82(6):1490-1500. 


\title{
Neurology ${ }^{\oplus}$ \\ Neuroimmunology \& Neuroinflammation
}

\author{
Allogeneic BK Virus-Specific T-Cell Treatment in 2 Patients With Progressive \\ Multifocal Leukoencephalopathy \\ Franziska Hopfner, Nora Möhn, Britta Eiz-Vesper, et al. \\ Neurol Neuroimmunol Neuroinflamm 2021;8; \\ DOI 10.1212/NXI.0000000000001020
}

This information is current as of May 17, 2021

Neurol Neuroimmunol Neuroinflamm is an official journal of the American Academy of Neurology.

Published since April 2014, it is an open-access, online-only, continuous publication journal. Copyright

Copyright $\odot 2021$ The Author(s). Published by Wolters Kluwer Health, Inc. on behalf of the American

Academy of Neurology.. All rights reserved. Online ISSN: 2332-7812.

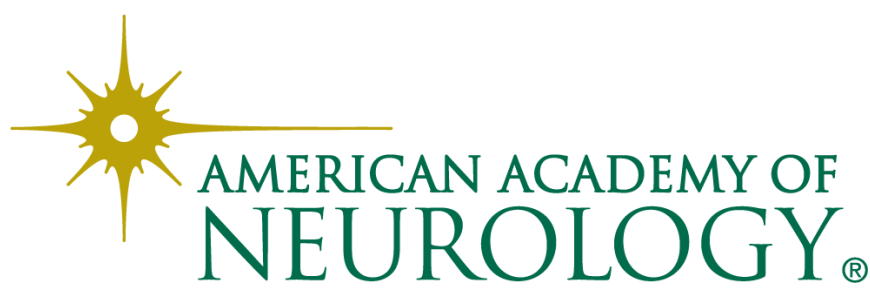




\section{Updated Information \& Services}

References

Subspecialty Collections

Permissions \& Licensing

\section{Reprints}

including high resolution figures, can be found at: http://nn.neurology.org/content/8/4/e1020.full.html

This article cites 13 articles, 0 of which you can access for free at: http://nn.neurology.org/content/8/4/e1020.full.html\#\#ref-list-1

This article, along with others on similar topics, appears in the following collection(s):

\section{All Imaging}

http://nn.neurology.org//cgi/collection/all_imaging

All Immunology

http://nn.neurology.org//cgi/collection/all_immunology

Autoimmune diseases

http://nn.neurology.org//cgi/collection/autoimmune_diseases

Class IV

http://nn.neurology.org//cgi/collection/class_iv

\section{Viral infections}

http://nn.neurology.org//cgi/collection/viral_infections

Information about reproducing this article in parts (figures,tables) or in its entirety can be found online at:

http://nn.neurology.org/misc/about.xhtml\#permissions

Information about ordering reprints can be found online: http://nn.neurology.org/misc/addir.xhtml\#reprintsus

Neurol Neuroimmunol Neuroinflamm is an official journal of the American Academy of Neurology.

Published since April 2014, it is an open-access, online-only, continuous publication journal. Copyright

Copyright $\odot 2021$ The Author(s). Published by Wolters Kluwer Health, Inc. on behalf of the American Academy of Neurology.. All rights reserved. Online ISSN: 2332-7812.

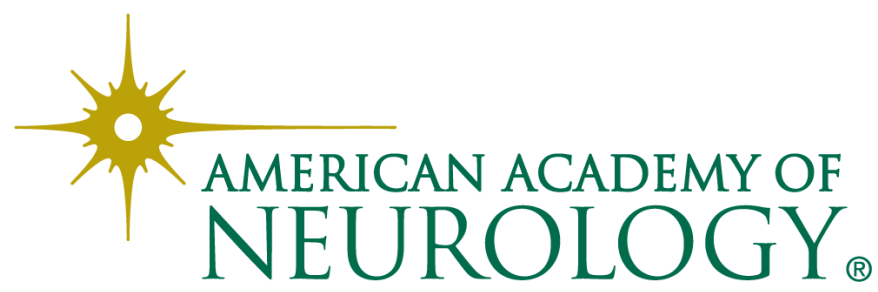

